\title{
An Analysis on the Path Design and Method of Military POL Professional Training Based on Professional Competence
}

\author{
Chen Jun \\ Department of Petroleum Supply Engineering, \\ Logistic Engineering University, \\ Chongqing, 401311, China
}

Yang Jing

Department of mechanical and electrical Engineering, Logistic Engineering University, Chongqing, 401311, China

\author{
Zuo Yonggang \\ Department of Petroleum Supply Engineering, \\ Logistic Engineering University, \\ Chongqing, 401311, China \\ Zhang Zhen \\ Department of Petroleum Supply Engineering, \\ Logistic Engineering University, \\ Chongqing, 401311, China
}

\begin{abstract}
Centering on the characteristics of military POL professional education of practicality, pertinence, forward looking and comprehensiveness, this paper proposes teaching design concept of "one center, two supports, three transitions" and introduces principles that should be adhered to, teaching method and teaching design model of POL professional training in military pre-job training.
\end{abstract}

Keywords-professional education; teaching design concept, teaching method

\section{THE CHARACTERISTIC OF MILITARY POL PROFESSIONAL EDUCATION}

Based on professional competence-oriented military POL professional training, its path is in accordance with military construction, oil support mode of future wars, overall strength of academies themselves, teaching advantages and development potential, and makes overall plan for cultivating military POL professionals in operation and maintenance of oil equipment, oil equipment management, oil support service and oil service command. Professional education for military POL profession is post-college vocational education, which is based on academic education, driven by the need of position in troops and centers on the cultivation of professional competence. Its characteristics are as follows.

\section{A. Practicability}

On the basis of making students master the basic POL theory, professional education of POL in military academies emphasizes the practical application such as operation, use, organization and command of oil equipment and oil test and highlights the cultivation of the ability to solve practical problems in post.

\section{B. Pertinence}

Professional education of POL in military academies is vocational education characterized by distinctive military profession, thus promoting students' subjectivity, developing their uniqueness and cultivating their creativity in order to facilitate harmonious development of students' personality.

\section{Forward looking}

In order to prevent teaching contents from lagging behind military construction, we should stay close to grassroots, keep up with latest information of military construction and update grassroots information so as to bring difficult points and hot issues in the POL professional training of grassroots troops into teaching contents, enrich teaching contents as well as keep pace with the times and blend new equipment, technologies, training methods and tactics into class.

\section{Comprehensiveness}

Students who have been trained have higher comprehensive qualities, which embodies in the unification of knowledge and ability, theory and practice, and life and work. Compared with academic education, professional education in military POL profession reflects two different educational values. Academic education plays a fundamental role in students' lifelong development, aiming to lay a solid foundation and enhance development potential and attaching great importance to students' long-term, stable and basic qualities. Professional education is designed to comprehensively enhance the professional competence and creative quality of cadres working in POL profession and lay emphasis on timeliness, pertinence and practicability of quality training in order to improve the abilities in political discernment, command and decision-making, coordination, organization work in grassroots level, management, ideological and political work, group training, exertion multiple types of military missions and so forth. 


\section{PATH DESIGN CONCEPT OF POL PROFESSIONAL TRAINING IN MILITARY PRE-JOB TRAINING}

Firmly focusing on the target of training students to have the ability to win and under the principle of emphasizing both theory and practice, the curriculum should stress the teaching concept that stay close to actual combat, strengthen the abilities in practice and enhance the post adaptability in accordance with the professional need of "knowing technology, being good at command and emphasizing ability". And this curriculum should center on students, highlight their subjectivity, focus on building the faith of devotion to national defense and loving post, and cultivate their abilities in use, management and group training of oil equipment. Meanwhile, this curriculum should also focus on the cultivation and improvement of students' application ability in oil equipment. Therefore, we should design teaching content, teaching procedures and reflections to guarantee the victory of modern war and bring the latest results of teaching, research, logistic theory and new methods and tactics in troops into teaching contents, which is reflected as follows:

\section{A. "one center"}

Centering on students, course teaching should transform from focusing on "teaching" into "learning", take into full consideration of students' real situation and job requirement, give full play to their subjective initiative and highlight their core status.

\section{B. "two supports"}

\section{1) Support by information-based teaching method}

We should make full use of information-based teaching method in the whole process of teaching, using multimedia to enrich teaching contents, 3D modeling and virtual prototype to show the difficult and important points and virtual simulation to recreate actual scene.

\section{2) Support by equipment group training}

Through training in single equipment, course teaching should integrate theory into practice with equipment group training at its core and strengthen the ability to command and use oil equipment. In addition, by using the kit in the environment of battlefield, it requires communication among academies to keep up with battlefields.

\section{C. "Three transitions"}

1) Promoting transition from one-way teaching into interactive discussion-based teaching

Based on pre-job training, course teaching should make full use of working experience of its students in order to create the teaching method of interaction, mutual stimulation and joint learning and try to prevent one-way "cram" teaching method.

\footnotetext{
2) Promoting transition from theoretical quality into practical ability

Course teaching should highlight ability training and strengthen case-based teaching to drill oil equipment and use, especially the experiences from major troops drills, which can enhance students' ability in working and actual combat.
}

\section{3) Promoting transition from class into battlefield}

By studying oil equipment and use in cases, examples of wars, drills, emergency response and multiple military actions, course teaching oriented toward battlefield should show modernization and informatization of military oil equipment and reflect hot issues and difficult problems of oil support in informationized local wars.

\section{PATH DESIGN AND METHOD OF POL PROFESSIONAL TRAINING IN MILITARY PRE-JOB TRAINING}

\section{A. The pre-job training of POL profession must adhere to the} principles of staying close to troops, equipments and posts.

We should combine with practical problems in oil training in grassroots troops, adapt to new situations and missions and update teaching content and thinking in time. Teaching content should stay close to troops, having similar situation with battlefield, strict regulations and direct practice. First, we should focus on the cultivation of fighting capacity in grassroots troops, bring new technology, equipment, tactics, training, theory and experience into course teaching and highlight the pertinence and effectiveness of teaching. Professional education for POL posts serves as the education of professional competence targeting at the actual requirement of posts, which is characterized by pertinence and effectiveness. If we don't understand the actual situation of troops, there will be phenomenon such as "theory divorcing from practice" and "focusing on format instead of content". Second, we should pay attention to the "benchmark" of professional education and strengthen the effectiveness of professional education on the basis of mastering capability. We should study the content setting of pre-job training by reaching grassroots troops, have an insight into the development and changes in present troops, carry out our education by aiming at the knowledge that grassroots POL cadres badly need and major theoretical and practical issues that need to be analyzed and solved in tenure. Meanwhile, we should develop stratified education in a scientific way, differentiate educational contents, objectives and methods in accordance with different targets and divide teaching into class teaching, group teaching and individual teaching in line with the way the two side of teaching interact according to different posts of students. And only when providing "targeted" curriculum and teaching content oriented toward "posts" can it promote efficient, sustained and stable development in POL professional education.

\section{B. Teaching method of POL pre-job training}

Various teaching methods such as lecturing, on-the-spot teaching, experiment teaching, practice teaching, visit teaching, virtual teaching, sand table exercise and exercise on map should be used in POL pre-job training. Among which, lecturing is a teaching mode of systematically imparting knowledge, the basic characteristic of which are to focus on lecturing, impart knowledge systematically to students and enhance their intelligence combined with self-studying and assignment in the light of the logical sequence of textbooks. On-the-spot teaching is a form of visual teaching which links actual situations to oil equipment objects (including simulation of situations and objects) with the main purpose of testing 
theories, providing perceptual knowledge and cultivating practical ability. On-the-spot teaching mainly includes the following procedures: showing theories, announcing or revealing situations, studying and exercising problems and commenting and summarizing. Experiment teaching refers to a kind of practical teaching mode in which students guided by instructors use related equipments to operate independently under certain condition in order to obtain direct experience and develop their abilities. Practice teaching requires that students should be organized to go to practice fields or troops to do some practical work so as to gain direct experience and knowledge, enhance POL professional skill and strengthen the ability to apply what you have learned to solve actual problems. Visit teaching is a type of teaching mode which organizes students to visit troops or other places in society according to professional teaching needs of POL and makes them perceive the objective world and reality through direct observation. Online teaching is an open network-based teaching form with multimedia information as its transmission medium. In virtual teaching, non-authenticity means can be used in both teaching and learning in order to gain real teaching effect, thus achieving the aims of saving educational expense, enlarging teaching areas and improving teaching. Although sand table exercise vividly and directly simulates the real fields in a more economic manner and frees from the influence of terrain, weather and seasons, it is hard to show detailed terrain, which has negative impact on some drills. Exercise on map is generally used by commander and in training. This exercise can configure situations in a larger area and offer a panorama of oil support operation in battlefield without the limitation of operation size.

\section{Actively promoting case teaching, reforming and innovating teaching method}

Case teaching guides students to discuss some particular problems hidden in specific and typical situations and events presented by cases. Therefore, we should actively promote case teaching in order to develop creative thinking and personality in understanding and solving problems and improve students' ability to solve practical problems. And we should apply oil support cases and hypothetical cases of battlefields into classroom and make grassroots cadres of POL profession act as all kinds of commanders in POL profession during pre-job training in order to train their command skills and stay close to missions of troops. In addition, we should improve teaching method and make great effort to enhance cooperative command capacity of grassroots cadres of POL profession. What's more, we should actively promote discussion-based teaching and stimulate the creative thinking ability of grassroots cadres. In the past pre-job training, course teaching is used to focusing on lecturing only supplemented by skill training and visit teaching, which has little training effect. Different from the objectives of academic education, pre-job training for grassroots cadres of POL profession emphasizes the improvement of their working competence. Therefore, there is no use in applying the model of academic education into professional education. Driven by the ability cultivation of grassroots cadres, we should achieve our training target by using basic methods such as study, research, exercise and practice. We should unleash cadres receiving training from passive study of theory instillation, promote some advanced teaching mode such as case teaching, discussion-based teaching and inductive teaching, actively carry out typical case analysis, discussion of hot issues and difficulties, hypothetical exercise and online simulated reasoning, inspire and expand innovation thinking of cadres receiving training, make on-the-spot teaching and actual combat drill become major forms and enhance cadres' ability in solving practical problems.

\section{CONCLUSION}

Based on professional competence-oriented military POL professional training, its path is in accordance with military construction, oil support mode of future wars, overall strength of academies themselves, teaching advantages and development potential, and makes overall plan for cultivating military POL professionals in operation and maintenance of oil equipment, oil equipment management, oil support service and oil service command. Centering on the characteristics of military POL professional education of practicality, pertinence, forward looking and comprehensiveness, this paper proposes teaching design concept of "one center, two supports, three transitions", that is centering on students, support by information-based teaching method and by equipment group training, promoting transition from one-way teaching into interactive discussion-based teaching, from theoretical quality into practical ability, from class into battlefield and introduces principles that should be adhered to, teaching method and teaching design model of POL professional training in military pre-job training.

\section{REFERENCES}

[1] Zhao Yongpu, Sticking to Connotative Development, Improving Educational Quality and Accelerating the Construction of High Level Innovative Military Comprehensive Universities[J]Journal of Naval University of Engineering(Integrated version),2013

[2] Zhu Changping, Exploration of Classroom Effective Teaching Practice Based on "program of Education and Training of Excellent Engineers"[J]Research and Exploration in Laboratory, 2012 